The University of Southern Mississippi

The Aquila Digital Community

Faculty Publications

$10-1-2018$

\title{
An Overview of Factors Affecting Distribution of the Atlantic Surfclam (Spisula solidissima), a Continental Shelf Biomass Dominant, During a Period of Climate Change
}

\author{
Eileen E. Hoffman \\ Old Dominion University \\ Eric N. Powell \\ University of Southern Mississippi \\ John M. Klink \\ Old Dominion University \\ Daphne M. Munroe \\ Rutgers University \\ Roger Mann \\ College of William and Mary
}

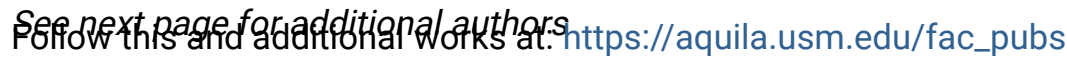

Part of the Marine Biology Commons

\section{Recommended Citation}

Hoffman, E. E., Powell, E. N., Klink, J. M., Munroe, D. M., Mann, R., Haidvogel, D. B., Narváez, D. A., Zhang, X., Kuykendall, K. M. (2018). An Overview of Factors Affecting Distribution of the Atlantic Surfclam (Spisula solidissima), a Continental Shelf Biomass Dominant, During a Period of Climate Change. Journal of Shellfish Research, 37(4), 821-831.

Available at: https://aquila.usm.edu/fac_pubs/16808

This Article is brought to you for free and open access by The Aquila Digital Community. It has been accepted for inclusion in Faculty Publications by an authorized administrator of The Aquila Digital Community. For more information, please contact Joshua.Cromwell@usm.edu. 


\section{Authors}

Eileen E. Hoffman, Eric N. Powell, John M. Klink, Daphne M. Munroe, Roger Mann, Dale B. Haidvogel, Diego A. Narváez, Xinzhong Zhang, and Kelsey M. Kuykendall 


\title{
AN OVERVIEW OF FACTORS AFFECTING DISTRIBUTION OF THE ATLANTIC SURFCLAM (SPISULA SOLIDISSIMA), A CONTINENTAL SHELF BIOMASS DOMINANT, DURING A PERIOD OF CLIMATE CHANGE
}

\author{
EILEEN E. HOFMANN, ${ }^{1 *}$ ERIC N. POWELL, ${ }^{2}$ JOHN M. KLINCK, ${ }^{1}$ DAPHNE M. MUNROE, ${ }^{3}$ \\ ROGER MANN, ${ }^{4}$ DALE B. HAIDVOGEL,${ }^{5}$ DIEGO A. NARVÁEZ, ${ }^{1,6}$ XINZHONG ZHANG ${ }^{5}$ \\ AND KELSEY M. KUYKENDALL ${ }^{2}$ \\ ${ }^{1}$ Center for Coastal Physical Oceanography, Old Dominion University, 4111 Monarch Way, Norfolk, VA \\ 23508; ${ }^{2}$ Gulf Coast Research Laboratory, University of Southern Mississippi, 703 E Beach Drive, Ocean \\ Springs, MS 39564; ${ }^{3}$ Haskin Shellfish Research Laboratory, Rutgers University, 6959 Miller Avenue, \\ Port Norris, NJ 08349; ${ }^{4}$ Virginia Institute of Marine Science, College of William \& Mary, 1375 Greate \\ Road, Gloucester Point, VA 23062; ${ }^{5}$ Department of Marine and Coastal Sciences, Rutgers University, 71 \\ Dudley Road, New Brunswick, NJ 08901; ${ }^{6}$ Departmento de Oceanografia, Universidad de Concepción, \\ Casilla 160-C, Concepción, Chile
}

\begin{abstract}
The Atlantic surfclam (Spisula solidissima) is a dominant member of the biological community of the Middle Atlantic Bight continental shelf and a commercially harvested species. Climate warming is affecting the biology and distribution of this species, which provides an opportunity to investigate the processes and conditions that are restructuring this fishery and the implications for ecological and socioeconomic systems. A Management Strategy Evaluation (MSE) developed for the surfclam fishery provides a mechanistic description of the surfclam's response to climate change and understanding of the cascade of effects initiated by changes in oceanographic conditions that ultimately appear as social and economic effects. This understanding in turn informs development of management policies for the resource. This overview considers the components of the surfclam MSE, relevant results, and implications for management and policy. The lessons learned from the surfclam MSE provide a basis for applying similar approaches to other ecologically important species that are also commercially exploitable resources.
\end{abstract}

KEY WORDS: Atlantic surfclam Spisula solidissima, Management Strategy Evaluation, climate change, surfclam fishery, Middle Atlantic Bight

\section{INTRODUCTION}

The Atlantic surfclam (Spisula solidissima) historically inhabited the continental shelf of eastern North America from Canada to Cape Hatteras at depths of 10-50 m (Abbott 1974, Ropes 1980). The surfclam has been a biomass dominant throughout much of this region since at least the initiation of the commercial fishery in the 1960s and comprehensive surveys in the late 1970s (Cargnelli et al. 1999) and contributes to the ecology of the benthic community by providing a primary source of sedimentary carbonate. Shell carbonate is known to buffer sedimentary acid, thereby facilitating recruitment of many species (Gutiérrez et al. 2003, Green et al. 2004, Waldbusser et al. 2010), providing shells that act as refuges for new recruits (Kraeuter et al. 2003, Guay \& Himmelman 2004), and providing bottom complexity that allows establishment of attached epifauna (Walker et al. 1998, Parsons-Hubbard et al. 2001, Brett et al. 2011). The surfclam and its deeper water analog, the ocean quahog Arctica islandica, support a commercial fishery that generates $\$ 1.3$ billion in economic value per annum (Murray personal communication), which represents a significant proportion of the Middle Atlantic Bight (MAB) commercial fishing industry (McCay et al. 2011).

In the 1960s, the range of the surfclam extended from Cape Hatteras to Georges Bank (Fig. 1) and to a lesser extent into the Gulf of Maine (Palmer 1991), with commercially viable concentrations throughout much of this range. Retrospective

*Corresponding author. E-mail: hofmann@ccpo.odu.edu DOI: $10.2983 / 035.037 .0412$ studies indicate that the southern inshore population in the MAB began to decline in the 1970s and 1980s, although early warning of climate change is poorly documented (compare Loesch \& Ropes 1977 and Ropes 1982 with Powell 2003 and NEFSC 2013). In the mid-1990s, the MAB surfclam stock was estimated to be at carrying capacity (NEFSC 2013) and the inshore surfclam stock reached historic highs off New Jersey. About 2000, the MAB surfclam biomass offshore of Delmarva began to decline (Table 1, McCay et al. 2011), with most significant declines along the southern and inshore boundary from Delaware Bay south (Weinberg et al. 2002, 2005, Kim \& Powell 2004). During the early 2000s, the inshore New Jersey population collapsed, and about the same time, the population abundance rose along the offshore range boundary off New Jersey (Weinberg et al. 2005) and along the inshore of Long Island (NEFSC 2013, 2017). Surveys during the 2000s suggested progradation of the offshore boundary off New York and an expansion of the population on Georges Bank (NEFSC 2013, 2017). Recent evidence suggests that surfclams also have expanded their range into deeper water on Georges Bank (Powell et al. 2017a) and east of Nantucket, west of the Great South Channel (Mann unpublished data). The recentness of these events is recorded in the distribution of surfclam shell, which slowly accumulates from surfclam mortality, and the limited shell content along the prograding boundary (Powell et al. 2017a).

These trends show that the southern boundary of the surfclam's range has receded northward and offshore during the past 3 decades in the region south of Hudson Canyon, whereas the offshore boundary has prograded offshore in the 


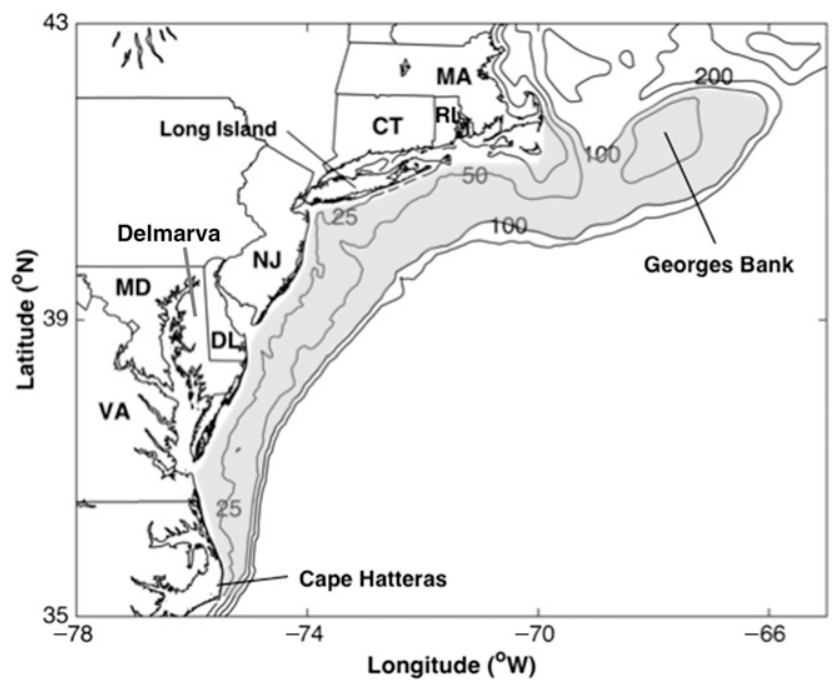

Figure 1. Map of the MAB region in the northwestern Atlantic continental shelf showing the current distribution of the Atlantic surfclam (shading). Geographic names used in the text are indicated.

same region and the population has expanded off Long Island and on Georges Bank. This northeastward and offshore progression has been attributed to warming of MAB bottom waters (Weinberg et al. 2002, Weinberg 2005). The decrease in biomass and shift in range has had significant implications for the surfclam fishery and its management (McCay et al. 2011, Powell et al. 2015a, Kuykendall et al. 2017).

The relationships among climate, oceanographic conditions, ecology, biology, the fishery, and management that presently influence surfclams involve a wide and disparate set of interconnected processes, mechanisms, and communities (Fig. 2). Climate provides an external forcing for the surfclam system. The temporal trends in geographic footprint recapitulate the expected population dynamics of a species undergoing a fundamental realignment to a changing thermal regime (Hutchins 1947, Holt et al. 2005). Through its effect on environmental conditions, specifically temperature, climate influences individual surfclams via modulation of physiological rates and

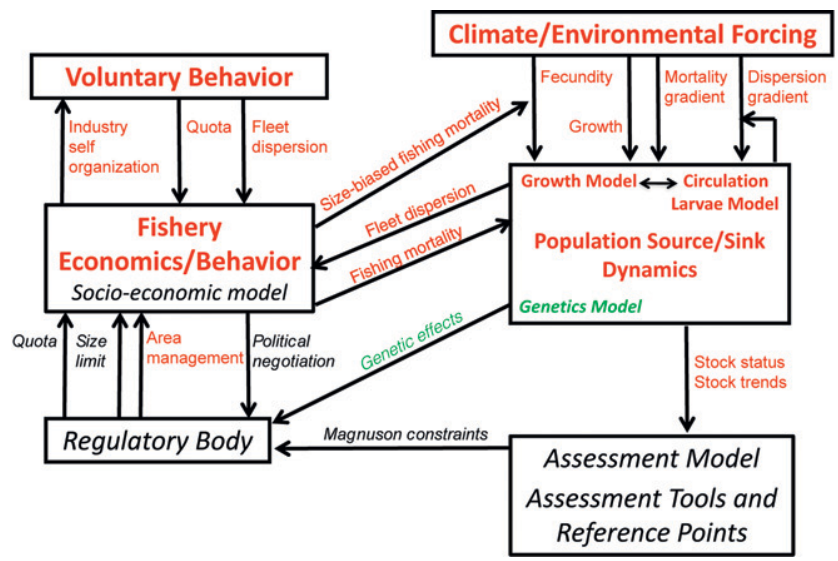

Figure 2. Conceptual outline of a surfclam MSE showing components that have been fully implemented (red text), those that are partially implemented (black text), and those that remain to be done (green text). influences overall population dynamics via effects on mortality and dispersion. The surfclam population is composed of source and sink subpopulations that are directly impacted by changing environmental conditions, the effects of which determine trends in overall population biomass, mortality, abundance, and reproduction. The environmental, ecological, and biological interactions produce biomass distributions that interface with the surfclam fishery and management structure through the statutorily mandated quota-setting process and through private business decisions and voluntary collective behavior (see overviews in McCay et al. 2011, Powell et al. 2015a).

Aspects of the surfclam-environment-fishery system have been described and quantified by observational and modeling studies; however, it is the complex linkages and interactions between and among the components of this system that affect changes in the distribution and biomass of the species with consequent effects on ecological, social, and economic systems. An approach that integrates these systems and their interactions with a consistent set of rules allows primary pathways to be identified that in turn point to the critical controlling linkages. A modeling-based approach that uses multiple linked models to evaluate outcomes across all system components, a Management Strategy Evaluation (MSE), meets this requirement (Miller et al. 2010, Bastardie et al. 2012, Martell et al. 2013). A surfclam MSE provides a conceptual basis that facilitates understanding of the cascade of effects initiated by changes in oceanographic conditions that ultimately appear as social and economic effects, which in turn inform development of management policies for the resource (Fig. 2).

The ecological and commercial importance of the surfclam resource warrants development of a comprehensive mechanistic description of its responses to forcings that extend from climate to management. The following sections describe implementation of important components of the conceptual surfclam MSE, with emphasis on quantifying and evaluating the mortality and dispersion gradients that control surfclam distribution and abundance (Fig. 2). The MSE is further developed to consider the surfclam fishery and its management (Fig. 2). The lessons learned from the surfclam MSE are a basis for applying similar approaches to other ecologically important species that provide community stability and long-term exploitable resources.

\section{SURFCLAM POPULATION-MORTALITY GRADIENT}

Surfclams are among the largest nonsymbiont-containing bivalves (compare Powell \& Stanton 1985, Roy et al. 2001) and their existence is a function of the productivity of the Delmarva to Georges Bank continental shelf (O'Reilly \& Busch 1984, O'Reilly \& Zetlin 1998, Yoder et al. 2002, Mouw \& Yoder 2005). Like most bivalves, surfclam adult size is dependent on the relative rates of respiration and ingestion; both are temperature controlled. In bivalves, respiration typically scales as the cube of the length (Powell \& Stanton 1985, Freitas et al. 2009, Powell et al. 2015b), whereas ingestion, which is a function of the two-dimensional surface of the gill, tends to scale as the square of the length (Powell et al. 1992, Hofmann et al. 2006, van der Meer 2006). This differential scaling produces physiological challenges for large-sized bivalves; at some point, ingestion is just able to meet respiratory demands and, perhaps, reproduction, and at that point, growth ceases. Temperature influences on respiration tend to follow a $Q_{10}$ relationship, with 
respiration increasing with rising temperature over the bivalve's physiological range (e.g., references in Powell \& Stanton 1985, Freitas et al. 2009). Ingestion, however, tends to follow a leftskewed parabolic relationship in which ingestion rate rises with increasing temperature up to an optimal level and then declines at a rapid rate as temperature continues to rise (e.g., Hofmann et al. 2006, Flye-Sainte-Marie et al. 2007, Munroe et al. 2013b). Because bivalves cannot shrink in linear size, but their meat weight can decline, a rise in temperature limiting ingestion and increasing respiration results in a loss of condition and ultimately death over an extended time.

Surfclams have a narrow optimal temperature range, which enhances the effect of small variations in temperature on growth. The animal experiences thermal stress at temperatures above $20^{\circ} \mathrm{C}$ and ceases growth at about $24^{\circ} \mathrm{C}$; higher temperatures are lethal to all surfclam life stages (Goldberg \& Walker 1990, Cargnelli et al. 1999, Zhang et al. 2015). By extension, the differential scaling of ingestion and respiration implies that stress-related mortality is higher in larger individuals within a local surfclam population; these individuals inherently have a lower scope for growth. Also, long-term exposure to suboptimal high temperatures can produce enhanced stress mortality (Woodin et al. 2013). Observations of increased mortality along the southern and inshore range boundary of the surfclam and the tendency for larger individuals to be most sensitive to this mortality source are consistent with temperature-induced starvation (Kim \& Powell 2004). This temperature sensitivity imposes a latitudinal and offshore mortality gradient on the surfclam stock (Weinberg 1999, Powell et al. 2015a), which is a basic control on population changes.

Food supply and temperature are primary environmental controls on surfclam production and biomass through their effect on population growth and mortality (Fig. 2). The contribution of both to the mortality gradient was assessed with a population growth model (Fig. 3), described in Munroe et al. (2013b), that is based on experimental studies that

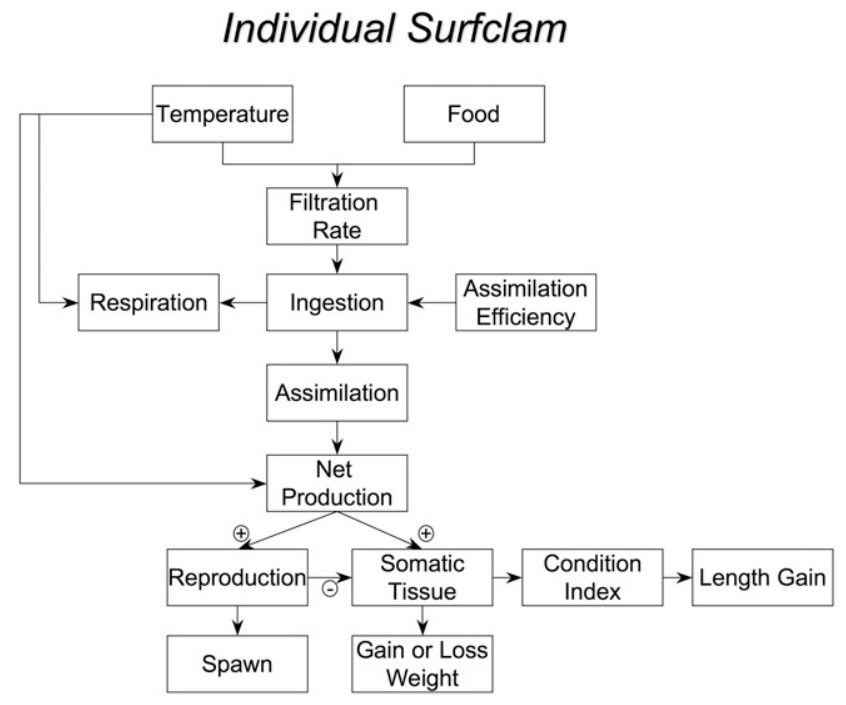

Figure 3. Schematic showing the processes included in the individual surfclam growth model. Net production depends on temperature, clam weight, and clam condition. Positive net production produces reproductive and somatic tissue, whereas negative net production causes resorption of reproductive tissue. Figure from Munroe et al. (2013b). provided quantification of physiological processes (filtration, respiration, growth, reproduction, and condition) of adult sessile surfclams. Assessments of food composition, food quantity, and timing of food delivery with the surfclam model showed that water column-based food, phytoplankton as represented by chlorophyll a measurements, can support only about $65 \%$ of the body mass of large $(160 \mathrm{~mm})$ surfclams (Munroe et al. 2013b). Provisioning of supplemental food from other sources, such as benthic production, was required to support observed surfclam size and biomass. The requirement for multiple food sources links surfclams to a range of environmental controls that are in turn moderated by climate. Among the potentially important unknowns is the feasibility of temperature-induced offshore movement of the stock because of light and nutrient supply controls on primary production. Surfclams exhibit reduced condition offshore (Marzec et al. 2010) and the extent to which this results from declining food supply in the offshore environment remains to be determined.

The surfclam vulnerability to rising bottom water temperatures was tested by forcing the surfclam growth model with a 50 -year (1958 to 2007) time series of simulated bottom water temperature obtained for the MAB from an implementation of the Regional Ocean Modeling System for the northwestern Atlantic (Kang \& Curchitser 2013). The growth model was implemented at sites along the MAB shelf where surfclams are found (Narváez et al. 2015). Simulation results showed that warmer, relative to average conditions, bottom temperatures reduced surfclam assimilation rate because of thermal stress, leading to starvation mortality and a decline in biomass; however, these simulations showed that the long-term observed decline in MAB Atlantic surfclam populations is a response to episodic warm years rather than a gradual warming trend in bottom water temperature. Temperature-driven population declines can persist for several years and have the largest effect on older and larger animals, which are the target of the commercial fishery. Episodic warm events that occur at a frequency exceeding the ability of the surfclam population to recover fully during intervening periods produce what appears to be a long-term decline in biomass. Continued episodic warming coupled with a long-term warming trend reduces biomass and results in a northward range shift. The occurrence of episodic warm events is potentially related to cross-shelf variability in the location of the cold pool, typically found on the Mid-Atlantic shelf between 40 and $90 \mathrm{~m}$ (Castelao et al. 2008). The inner margin of the cold pool approximates the offshore extension of the surfclam's range. The large-scale surfclam mortality event recorded off Delmarva in the early 2000 s coincides with a particularly large offshore excursion of this cold water mass (Sha et al. 2015). The cross-shelf instability in the cold pool has been associated with the North Atlantic Oscillation and the extreme mortality event in 2000 coincides with a northern hemisphere regime shift linked to the Atlantic Multidecadal Oscillation (Lucey \& Nye 2010); both coincidences implicate climate as an important driver behind the geographic trends in the surfclam stock distribution.

Observations suggest a decrease in surfclam size of 15-20 mm since the early $1980 \mathrm{~s}$ in the federally surveyed stock, which scales to a $39 \%$ biomass decline over this time for the largest living individuals (Munroe et al. 2016). Fishing, a nonenvironmental source of mortality, and thermal stress were suggested as causes for this decrease as both mechanisms are well-established 
determinants of size (Hofmann et al. 1994, Landi et al. 2015). To evaluate the relative contribution of both, a range of sizeselective fishing pressures was applied to surfclam populations experiencing bottom water temperature represented in the 50-year MAB temperature time series and population growth was simulated (Munroe et al. 2016). The simulations showed that either effect in isolation is not sufficient to produce the observed decline in size, except at the extremes. The combined effect of both could, however, generate size decreases that are consistent with observations, as could interannual variations in temperature, which might result in decadal-scale shifts in size. These simulation results implicate fishing and surfclam physiological responses to climate as causal mechanisms that establish gradients in mortality and size of the largest animals over the range of the stock.

\section{LARVAL TRANSPORT-DISPERSION GRADIENT}

Propagule dispersal has received increasing attention as a primary modulator of the response of populations to changing environmental regimes (O'Connor et al. 2007, Selkoe \& Toonen 2011, Travis et al. 2013). The larval dispersion gradient establishes and maintains the biomass and range of the surfclams and provides the link between climate, environment, and surfclam subpopulations (Fig. 2). The dispersion gradient arises from interactions of surfclam larvae with the circulation. The larvae provide coupling between the dispersion and mortality gradients by providing inputs to the adult sessile population. Variable dispersion affects the distribution of source subpopulations such that population expansion does not occur equivalently everywhere. Thus, describing and understanding controls on this gradient are integral to application of the MSE.

Surfclam larval transport pathways and subpopulation interconnectivity were simulated using a coupled modeling system that combined a Regional Ocean Modeling Systembased circulation model implementation for the MAB, Georges Bank, and the Gulf of Maine (Fig. 1) and an individual-based surfclam larva model that simulates larval growth and behavior (Zhang et al. 2015, 2016). The latter permits surfclam larvae to move vertically in the water column, which is essential for simulating transport (Shanks \& Brink 2005, Ma et al. 2006). The model was used to evaluate the possibility that the observed decline in surfclams along the southern boundary (from 1997 to 2005) resulted from reduced larval input, leading to poor recruitment, and to examine mechanisms that allowed the stock range to shift both to the northeast and offshore.

The simulated circulation distributions show a pattern of net along-shelf southward flow on the MAB shelf that is consistent with observations (Beardsley \& Boicourt 1981). Particles representing surfclam larvae were released into the simulated flow fields at locations that correspond to observed surfclam distributions, at times that correspond to the surfclam spawning season (May to October), and at numbers proportional to surfclam density (details in Zhang et al. 2015). The time- and space-dependent trajectory of a simulated larva was tracked in the flow field until the larva satisfied the criteria for setting by reaching settlement size $(260 \mu \mathrm{m})$ within 35 days of release and by being within the potential settlement habitat (shallower than the 60-m isobath) anywhere on the shelf. Any larva not satisfying these criteria was assumed to be unsuccessful.
Analysis of the transport pathways for successful larvae showed an along-shore connectivity pattern from northeast to southwest for surfclam populations distributed from southern New England south along the MAB shelf, suggesting considerable interpopulation connectivity throughout much of the surfclam population range. The planktonic larval duration is sufficient for surfclam larvae to drift over $100 \mathrm{~km}$ along the shelf. Variability in larval drift distance is imposed by the circulation and temperature, which influence larval growth and development. The simulated trajectories showed that larvae were continuously provided to the regions along the surfclam southern range boundary from more northerly source regions, implying that this region receives a sufficient larval supply. Thus, failure to repopulate the inshore region off Delmarva and the waters off New Jersey since the demise of surfclams in both regions in the early 2000 s is unlikely to be a result of inadequate larval supply.

The larval trajectories show that northward expansion of the surfclam range is inhibited by the net southward transport. The development of the inshore Long Island surfclam population may be attributed to the southward transport of larvae spawned in southern New England, although northward movement of simulated particles around the inshore reach of Hudson Canyon, though rare, does occur (Zhang et al. 2015). The simulated particle trajectories offer a possible mechanism for offshore surfclam expansion. Seasonal shifts in particle trajectories occurred, with preferential movement inshore during one portion of the spawning season and offshore during other periods (Zhang et al. 2016). An extended spawning season (Ropes 1968, Jones 1981), noteworthy for surfclams, allows taking advantage of this differential in transport. Offshore expansion of surfclams into deeper continental shelf waters has been observed, but extension to the northeast is undocumented. Surfclams have failed to move northward across Hudson Canyon to populate the central continental shelf, for example, despite high clam abundances on the Canyon's southern edge (NEFSC 2017).

The surfclam population is characterized by a patchy distribution, which poses challenges for surveying the stock and tracking the shift in range (Powell \& Mann 2016, Powell et al. 2017b). The dynamics of range shifts have been considered, as has the importance of source and sink populations in determining the stability of the leading edge and the potential for genetic variation across the range core to range edge transition (Ibrahim et al. 1996, Excoffier et al. 2009, Hellberg 2009). Evaluation of range shift dynamics at this scale for surfclams has not occurred, although Hare et al. (2016) rated the vulnerability of the surfclam to climate change as "very high," suggesting that this species is likely a bellwether for climate change in the northwestern Atlantic.

\section{SURFCLAM FISHERY-SOCIAL AND ECONOMIC INPUTS}

The fishery is the second major component of the surfclam MSE (Fig. 2) and includes the economic and sociological interconnections and responses, as well as interactions and responses to environmental and biological conditions and constraints. These interactions determine fishery responses to the stock and its influences through fishing pressure and dispersion of mortality over stock size and range through 
interactions with regulatory bodies and the use of voluntary behavior or self-regulating behavior within the fishery (Fig. 2).

The surfclam fishery uses hydraulic dredges with catch efficiencies typically exceeding 70\% (Thorarinsdóttir et al. 2010, Hennen et al. 2012, NEFSC 2013). Most surfclam fishing vessels have limited refrigeration capacity, which limits time at sea from the initiation of fishing to landing to less than $48 \mathrm{~h}$ in the warmer months. Thus, the fishery requires high landings per unit effort (LPUE) and, as a result, targets surfclam patches of high density. Vessel performance is a function of vessel characteristics (e.g., steaming speed and dredge width) and the captain's approach to fishing. Incorporation of these characteristics of surfclam fishing vessels and the fishery, and explicit treatment of human behavioral responses requires inclusion of vessel-specific characteristics, captains' behavior and decisionmaking, and processor-imposed landing constraints (Walters 2000, Dorn 2001, Millischer \& Gasuel 2006, Bertrand et al. 2007) as shown in an expanded surfclam MSE (Fig. 4). Behavioral characteristics that influence the decision of where to fish include the tendency to communicate among captains, use of survey data, searching behavior, and the integration of catch history over a range of time spans (Powell et al. 2015a, Powell et al. 2016).

Simulations of the surfclam fishery using the expanded MSE showed that modest improvements in LPUE were obtained if captains' behavior included reliance on recent catch history, moderate searching, or use of survey data. Modest reductions in performance occurred as a result of frequent searching, often from communication with other captains, and typically from integration of catch history over extended time periods. The behaviors that increased LPUE are consistent with the efficient identification of high-density patches of surfclams and the repeated return to these patches until patch density declines. This behavior matches records of LPUE trends within the stock and the patchy dispersion of the fleet in most years (NEFSC 2013); however, the influence of vessel characteristics and captains' behavior are modest relative to the locations of ports of call, which restrict the geographic footprint exploitable by

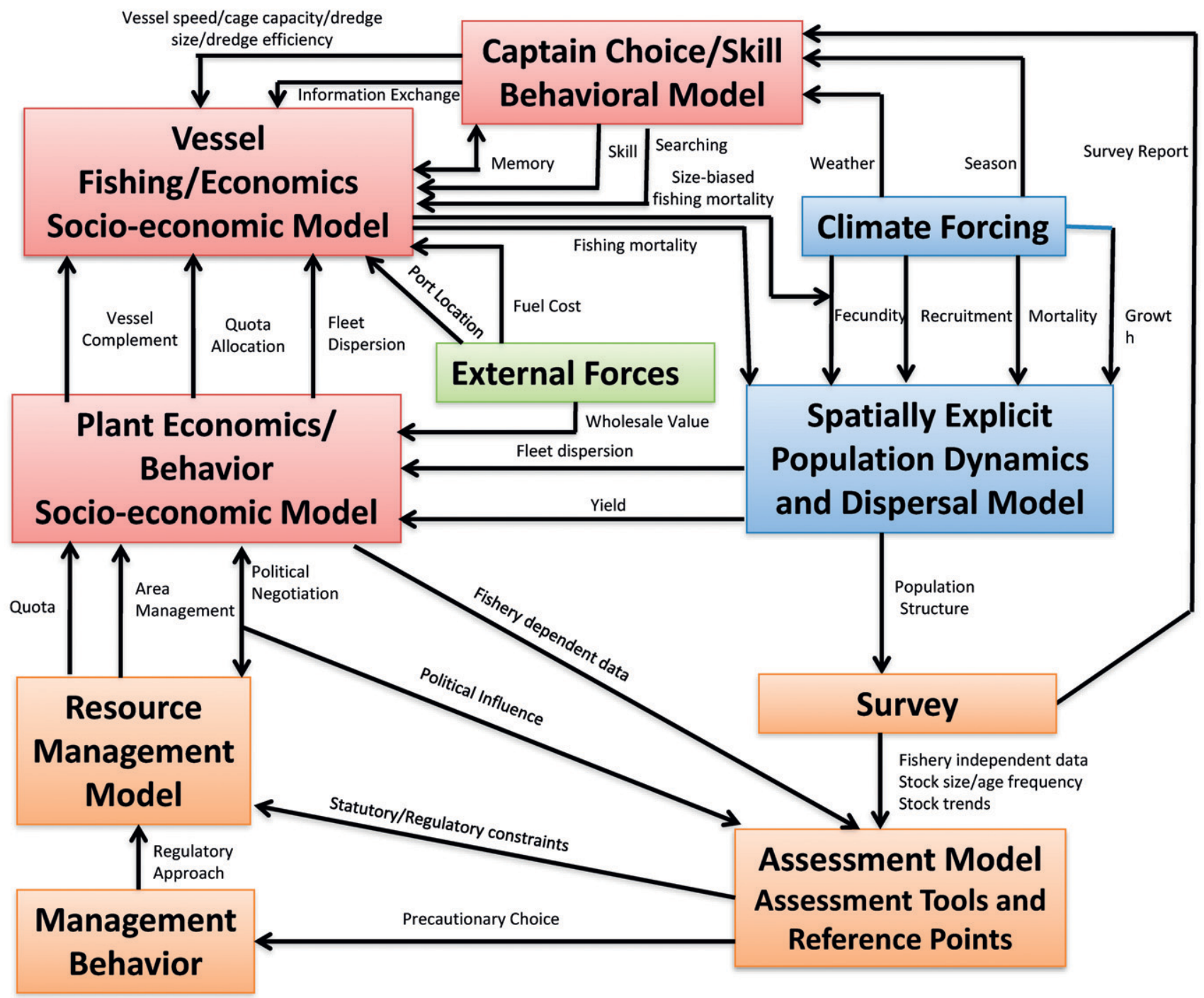

Figure 4. Structure of the expanded surfclam MSE showing population dynamics components (blue), survey and management components (orange), external forces (green), and industry structure and function (pink). Figure from Powell et al. (2015a). 
any given fishing vessel. A principal impact of MAB warming has been to force the fishery to operate out of more northerly ports, which has dislocated participants and disadvantaged southern ports (Powell et al. 2015a, Powell et al. 2016). Also, southern processing plants have been displaced by those to the north.

Simulations that included explicit behavioral choices for captains of fishing vessels with varying performance and economic return potential were used to evaluate mitigation strategies that allow continued fishing and viable economic returns during a period of stock decline as occurred in the early 2000s (Powell et al. 2016). These results showed that the LPUE declined because lower surfclam abundance required an extended time at sea to catch a full load. Vessels had to steam farther from port to occupy an expanded region to maintain LPUE performance. Net revenue declined. The use of survey data by the captain significantly improved performance as did moderate searching. Reliance on a long period of catch history failed to improve performance because the information was out of date during a time of rapidly changing conditions. In these simulations, abundance never dropped low enough to trigger a quota reduction under federal guidelines, yet no captains' behaviors prevented a collapse in vessel economics at these minimally low abundances, although certain behaviors limited the degree of economic dislocation. This outcome was determined by the influence of declining abundance on the density of high-density clam patches required by the fishery. That is, the disappearance of high-density patches occurred long before the stock itself was in danger of being overfished. The LPUE constraint under which the surfclam fishery operates shows that the industry is much more sensitive to climate change and a shift in stock range than is the stock itself.

The surfclam MSE allows evaluation of alternative management strategies that simultaneously address the two primary challenges facing sustainability of the surfclam stock and fishery: range contraction limiting stock abundance and a decline in the number and density of dense surfclam patches limiting the fishery. Simulations that implemented rotating closures as a management tool, based on the success of this approach for sea scallops Placopecten magellanicus (Hart \& Rago 2015), were used to evaluate the effects of closure durations from 3 to 7 years, criteria for identifying areas for closure based on the true abundance or the proportional abundance of small surfclams, and a range of definitions for a small surfclam based on the time required for growth to market size $(120 \mathrm{~mm})$ (Kuykendall et al. 2017).

Simulation results showed that choice of area for closure based on proportional abundance of small surfclams performed best with closure durations of 4-5 years and with small surfclams defined as $80-120 \mathrm{~mm}$ or $93-120 \mathrm{~mm}$ in size, requiring 3-4 years to reach market size $(\geq 120 \mathrm{~mm})$. Closure of one 10 -min square $(10$ min latitude $\times 10$ min longitude) per year resulted in a stock-wide increase in abundance over time because larger surfclams were taken to market and fewer of these were required to fill a bushel. The fishery is managed based on volume (bushel or cage), so removal of fewer surfclams per volume allows the stock abundance to increase. In addition, closure of one 10-min square per year resulted in increased LPUE because the areas opened each year contained highdensity surfclam patches. Thus, area management based on time-limited closures enhanced the stock and improved the fishery (Kuykendall et al. 2017).

\section{DISCUSSION}

\section{Environmental Perspective}

Assessment of the surfclam stock has occurred every 2-3 years since 1982. Since the introduction of individual transferable quotas in 1990 with the addition of Amendment 8 to the original fisheries management plan (Weninger 1998; see also McCay et al. 1995, Adelaja et al. 1998), the fishery has not been judged to be overfished, nor has overfishing been found to be occurring (see Blackhart et al. 2006 for definitions). Thus, climate change and the well-documented shift in range have not endangered the stock, as generally determined under federal guidelines (e.g., Applegate et al. 1998). This outcome is in part not only due to the extensive range and biomass of the stock as it existed in the mid-1990s but also because the decline in biomass at the southern and inshore portion of the range has been more or less balanced by the increase in abundance offshore of New Jersey, along Long Island, and on Georges Bank. The mortality event off Delmarva circa 2000, however, alerted the scientific community to a historic shift in range that had likely been ongoing well before the event and which initially generated concern about the resiliency of the stock to global climate change. This concern has not been fully allayed, but that the surfclam is a sensitive bellwether of climate change in the MAB is now well documented.

The analysis presented in Narváez et al. (2015) shows that the mortality event circa 2000 occurred not because water temperatures exceeded the surfclam's thermal limit but rather because the surfclam was in a thermal range, termed the transient event margin by Woodin et al. (2013), that compromised its energetics, leading to increased morbidity and ultimately death. The dominance of large adult individuals (Weinberg 1998), particularly sensitive to physiological constraints, exacerbated the degree and rapidity of this mortality event. The frequency of episodic warm events on the MAB shelf increased in the 1980s such that more than one event occurred within the lifetime of the surfclam (about 30 years). The result was a decreasing ability for the population to recover between events, producing a recession of the southern and inshore boundary of the range that likely began in the 1970s and continued over many years. The net southward transport on the MAB shelf suggests that populations at the southern boundary receive sufficient larvae to recover from mortality events, which would allow rebuilding the stock during times of favorable conditions. This outcome has not occurred, adding further support to the suggestion that mortality is the result of cumulative physiological stress and not a failure in larval supply. An alternative to physiological stress limiting recovery is a possible increase in juvenile predation. Small surfclams can be heavily preyed upon (MacKenzie et al. 1985, Dietl \& Alexander 1997, Quijón et al. 2007). Northward range shifts by potential predators are not well documented but, perhaps, might be expected (e.g., Polyakov et al. 2007).

About two-thirds of the food demand for surfclams can be satisfied by water column-based sources (Munroe et al. 2013b). The MAB has large fall/winter phytoplankton blooms along the 
inner shelf, where surfclams are abundant. The magnitude of these blooms is declining, which has been related to delayed erosion of the fall stratification and deeper winter mixing, which limits light (Schofield et al. 2008). The net 14\% decrease in MAB chlorophyll-based production over the past 40 years (Schofield et al. 2008) potentially exacerbates the physiological stress imposed by temperature, contributing further to the sensitivity of surfclams to starvation mortality.

Much of the food supply along the inner shelf of the MAB is likely provided by production associated with summer upwelling, such as that occurs off the coast of New Jersey (Neuman 1996, Chintala \& Grassle 2001, Castelao et al. 2008) where surfclam biomass is still high. Changes to the timing, strength, and extent of coastal upwelling centers have important consequences for food availability and the ability to acquire food, both of which constrain surfclam production.

The combination of reduced food supply and temperatureinduced physiological stress, possibly abetted by fishing pressure, has produced a trend toward MAB surfclam populations that consist of smaller animals. The offshore expansion of the population into deeper water with limited capacity for benthic photosynthesis and inherently restricted organic carbon supply (Rowe et al. 1988) may impose an insurmountable constraint on the southern portion of the stock as MAB warming proceeds because the entirety of the continental shelf may not be accessible for colonization even with favorable bottom water temperatures. The extent of the offshore expression of the upwelling phenomenon places a further potential constraint on the successful offshore shift in the surfclam's range as MAB warming proceeds. The trend toward smaller animals has implications for the fishery, which subsists on dense beds of surfclams greater than or equal to $120 \mathrm{~mm}$ with a preference for individuals greater than or equal to $150 \mathrm{~mm}$.

\section{Fishery Perspective}

The surfclam fishery was relatively unimpacted by warming of the MAB until the early 2000s. The relative stability of fleet structure and dispersion and the location of processing plants were disrupted by a sudden and catastrophic collapse of the stock off Delmarva circa 2000, although abandonment of a primary landings port in Virginia occurred some years earlier, presaging the acceleration of the shift in range that began in 2000. The environmentally induced northward progression of the southern range boundary and the limited progression of the northern range boundary mean that a smaller and more northerly biased region of the MAB now supports the surfclam fishery. Expansion of the stock offshore of New Jersey and Long Island provided only modest improvement. Until 2013, the larger expansion of the stock on Georges Bank remained unaccessed because of a closure of Georges Bank in 1990 initiated by a paralytic shellfish poison event (Jacobson \& Weinberg 2006). As a consequence, the bulk of the surfclam fishing fleet was concentrated on the New Jersey continental shelf.

In response to the shift in surfclam distribution, fishing vessels were moved from southern ports, resulting in closure or near-closure of southern surfclam fishing ports in Virginia and Maryland. Surfclam processing capacity moved to more northern locations. Processing plants in Virginia were closed and new capacity was built in Massachusetts. Fishing pressure became concentrated in a smaller region and regional fishing mortality rate increased substantively off New Jersey. The LPUE declined as dense surfclam patches were fished down, impacting the economic viability of the fishery. Reopening of Georges Bank provided additional resources to the fishery (NOAA 2012), but only a small subset of vessels in the fleet have the steaming speed and fishing capacity to take advantage of that resource. As a result, the challenge imposed by geographic constriction of the stock south of Hudson Canyon continues only somewhat abated.

The effects of climate change on the MAB are ongoing, which makes continued sustainability of the surfclam stock and survival of the surfclam fishery dependent on choices made in siting processing plants, by owners and fleet captains in deployment of the fishing fleet, and by managers in improved survey and assessment of technology. These decisions have economic consequences for the location of ports for the fishing fleet, location of processing plants, the type and size of fishing vessels, and the management of the stock. The ambit of the response of the surfclam to further warming of the MAB is restricted, which means that improving stock productivity is essential.

The MSE identified rotating closures as a management option that may provide improved stock performance and improved fishery economics (Kuykendall et al. 2017). This approach takes advantage of the rapid growth of surfclams to market size and patchy recruitment, and the landings are measured in volume rather than number. Rotating closures provides husbandry of surfclam patches that will ultimately improve LPUE as well as stock productivity. The MSE suggests that full implementation of a rotating closure plan could generate a substantive improvement in stock productivity and provide a substantial economic benefit to the fishery.

\section{Management Strategy Evaluation Perspective}

The implementation of the surfclam MSE is through a series of interlinked yet distinct models that address climatic, environmental, population, and fishery constraints on surfclam distribution and abundance. Each model provided insights about specific processes that regulate surfclams. The strength of the MSE is in linking outputs from the models to ultimately provide guidance for management for stock conservation that will maintain a viable fishery.

The MSE, however, has important components that remain to be developed and implemented. The genetic makeup of the surfclam population is a critical determinant of its ability to respond and adapt to environmental change. The genetic model indicated in the conceptual MSE allows mapping of physiological function to specific alleles and genotypes, thus providing a mechanistic understanding of endogenous genetic and physiological factors affecting recruitment success. The importance of genetic diversity in establishing species success at range centers and range boundaries has received considerable attention (Holt 2003, Excoffier et al. 2009, Hellberg 2009). Adult surfclams produce larvae with specific genotypes and with prescribed relative fitness. Inclusion of a genetic component in the adult 
and larva models allows prediction of the likelihood of survival for individual genotypes (e.g., Munroe et al. 2013a, 2015). Also, changes in genetic composition as a function of the effective number of parents (random genetic drift) and of adult and larval genotypes (selection) and the effects of episodic immigration by recruits with variable genotypes can be assessed. This capability within the MSE allows the genetic aspect of range shift to be investigated and evaluation of the role of genetic bottlenecks and fishing in controlling overall population genetic structure.

Further decline in surfclam abundance resulting from climate change, should the species be unable to maintain stock size under a future thermal regime, can be expected to increase uncertainty about the future viability of the fishery; whether novel management options exist under this circumstance remains uninvestigated. Assessment, regulatory, and socioeconomic components of the conceptual MSE are included in the expanded MSE that allow assessing the impact of and responses to a changing surfclam stock and fishery. However, knowing the range of potential impacts and responses is not sufficient. Effective communication of these to managers, policy makers, and the public is needed to close the loop between scientific understanding and management such that effective policies and regulations can be developed to support a sustainable surfclam fishery.

\section{Lessons Learned}

The surfclam MSE frames this case study in terms of environmental and human pressures that directly interact with and affect the animal. Analyses of interactions allow insights from what happened in the past to inform current conditions and to project possible responses to future climate change. An important lesson from this analysis is the need to detect and project change at time scales that allow implementation of mitigation and adaptation strategies. Recruitment to the surfclam population was ongoing in the 1980s and 1990s, but biomass was declining along the southern range boundary and animal size was getting smaller. Explanations at the time, such as food limitation and stunting for small size (Weinberg 1998) and overfishing for declining abundance (Ropes 1982), failed to recognize what in retrospect was a clear early warning signal of MAB warming and the initiation of a range shift. The deleterious effects of high, but sublethal, temperatures and the changing frequency of episodic warm events went unrecognized. Had either of these environmental effects been part of a larger view of controls on the stocks, management strategies could have been implemented to ameliorate the effects of the eventual collapse of the fishery along the southern range of the species.

As Roy et al. (2001) have shown, large benthic bivalves are bellwethers for climate change and they might be considered as nature's early warning system on the continental shelf. Taking the surfclam as a case study, the MSE provides guidance on critical metrics that can be used to evaluate the influence of climate on population dynamics. Clearly, monitoring of bottom water temperatures and food supply are important. Size decrease of the largest animals is potentially an early warning signal of the effects of climate change as maximum size integrates a range of environmental drivers of physiology. Cumulative stress has more of an effect on larger animals, making them less likely to survive. Monitoring the size of the largest animals, their condition, and their mortality rate, coupled with temperature and food supply, could detect climate change effects with sufficient time to develop strategies to protect shellfish fisheries and to anticipate large-scale changes in the continental shelf benthic ecosystem.

The net southward transport of water along the MAB will continue to provide larvae that can maintain surfclam populations in the southern end of its range. Southward expansion of populations during cooling times is facilitated by this transport. By contrast, northward expansion during warming times is inhibited. Continued warming of bottom water temperatures will push surfclams into a smaller geographic footprint or populations will need to expand northward against this net flow or offshore. Extensive regions of the continental shelf provide potential habitat offshore of New Jersey and Long Island eastward into southern New England, if food supply permits. The differential shift in bottom water temperature relative to the light gradient may determine the viability of these regions as surfclam habitat. The difficulty with sustaining populations at the northward end of the range comes from the lack of consistent connectivity between the MAB and systems to the north, for example, Georges Bank and the Gulf of Maine, and the restriction of habitat in the north. The surfclam range extends into the Gulf of Maine (Palmer 1991), but restricted habitat limits the extent of regionally extensive beds to Georges Bank. Simulations of transport of scallop larvae spawned on Georges Bank show that recruitment to the MAB is possible (Tian et al. 2009); however, recruitment is intermittent and dependent on the coincidence of several biological (e.g., spawning time) and physical (Scotian Shelf circulation) factors. Surfclam larvae spawned on Georges Bank can reach the southern New England shelf, but the degree to which Georges Bank is a primary source population remains unknown (Zhang et al. 2015, 2016).

What is clear is that surfclam populations at the southern end of the MAB range are sink populations that provide larvae to habitats that can no longer sustain viable populations, so that the broodstock for the surfclam may be restricted geographically even more than the stock as a whole as MAB warming proceeds. The case study provided by the surfclam provides insights into what may occur for other sessile biomass dominants on the continental shelf as climate change progresses and emphasizes the possibility of catastrophic reorganization of the continental shelf benthos in a region where restricted habitat and larval dispersal north limit response to rising temperatures in the south.

\section{ACKNOWLEDGMENTS}

This research was supported by the National Science Foundation Coupled Natural and Human Systems grant number 0908939 and by the NSF Industry/University Cooperative Research Center SCeMFiS (Science Center for Marine Fisheries) (grant number 1266057) under the direction of the SCeMFiS Industry Advisory Board. The COPAS Sur-Austral (PFB-31) and MINECON - NC120086 provided additional funding for D. Narváez. Conclusions and opinions expressed herein are solely those of the authors. 


\section{LITERATURE CITED}

Abbott, R. T. 1974. American seashells, $2^{\text {nd }}$ edition. New York, NY: Van Nostrand Reinhold Co. 663 pp.

Adelaja, A., B. McCay \& J. Menzo. 1998. Market share, capacity utilization, resource conservation, and tradable quotas. Mar. Resour. Econ. 13:115-134.

Applegate, A., S. Cadrin, J. Hoenig, C. Moore, S. Murawski \& E. Pikitch. 1998. Evaluation of existing overfishing definitions and recommendations for new overfishing definitions to comply with the sustainable fisheries act. Final Report, Overfishing Definition Review Panel, June 17, 1998, U.S. Department of Commerce, National Marine Fisheries Service. 179 pp.

Bastardie, F., M. Vintehr, J. R. Nielsen, C. Ulrich \& M. S. Paulsen. 2012. Stock-based vs. fleet-based evaluation of the multi-annual management plan for the cod stocks in the Baltic Sea. Fish. Res. 101:188-202.

Beardsley, R. C. \& W. C. Boicourt. 1981. On estuarine and continentalshelf circulation in the Middle Atlantic Bight. In: Warren, B. A. \& C. Wunsch, editors. Evolution of physical oceanography: scientific surveys in honor of Henry Stommel. Cambridge, MA: The MIT Press. pp. 198-233.

Bertrand, S., A. Bertrand, R. Guevara-Carrasco \& F. Gerlotto. 2007. Scale-invariant movements of fishermen: the same foraging strategy as natural predators. Ecol. Appl. 17:331-337.

Blackhart, K., D. G. Stanton \& A. M. Shimada. 2006. NOAA fisheries glossary. NOAA Technical Memorandum NMFS-F/SPO-69. 61 pp.

Brett, C. E., K. M. Parsons-Hubbard, S. E. Walker, C. Ferguson, E. N. Powell, G. Staff, K. A. Ashton-Alcox \& A. Raymond. 2011. Gradients and patterns of sclerobionts on experimentally deployed bivalve shells: synopsis of bathymetric and temporal trends on a decadal time scale. Palaeogeogr. Palaeoclimatol. Palaeoecol. 312:278-304.

Cargnelli, L. M., S. J. Griesbach, D. B. Packer \& E. Weissberger. 1999. Atlantic surfclam, Spisula solidissima, life history and habitat characteristics. NOAA Technical Memorandum NMFS-NE-142. $13 \mathrm{pp}$.

Castelao, R., O. Schofield, S. Glenn, R. Chant \& J. Kohut. 2008. Crossshelf transport of freshwater on the New Jersey shelf. J. Geophys. Res. Oceans 113:1-12.

Chintala, M. M. \& J. P. Grassle. 2001. Comparison of recruitment frequency and growth of surfclams, Spisula solidissima (Dillwyn, 1817), in different inner-shelf habitats of New Jersey. J. Shellfish Res. 20:1177-1186.

Dietl, G. P. \& R. R. Alexander. 1997. Predator-prey interactions between the naticids Euspira heros Say and Neverita duplicata Say and the Atlantic surfclam Spisula solidissima Dillwyn from Long Island to Delaware. J. Shellfish Res. 16:413-422.

Dorn, M. W. 2001. Fishing behavior of factory trawlers: a hierarchical model of information processing and decision-making. ICES J. Mar. Sci. 58:238-252.

Excoffier, L., M. Fall \& R. J. Petit. 2009. Genetic consequences of range expansions. Annu. Rev. Ecol. Evol. Syst. 40:481-501.

Flye-Sainte-Marie, J., F. Jean, C. Paillard, S. Ford, E. Powell, E. Hofmann \& J. Klinck. 2007. Ecophysiological dynamic model of individual growth of Ruditapes philippinarum. Aquaculture 266:130-143.

Freitas, V., J. F. M. F. Cardoso, S. Santos, J. Campos, J. Drent, S. Saraiva, J. I. J. Witte, S. A. L. M. Kooijman \& H. W. van der Veer. 2009. Reconstruction of food conditions for northeast Atlantic bivalve species based on dynamic energy budgets. J. Sea Res. 62:75-82.

Goldberg, W. \& R. L. Walker. 1990. Cage culture of yearling surfclams, Spisula solidissima (Dillwyn, 1817), in coastal Georgia. J. Shellfish Res. 9:187-193.

Green, M. A., M. E. Jones, C. L. Boudreau, R. L. Moore \& B. A. Westman. 2004. Dissolution mortality of juvenile bivalves in coastal marine deposits. Limnol. Oceanogr. 49:727-734.
Guay, M. \& J. H. Himmelman. 2004. Would adding scallop shells (Chlamys islandica) to the sea bottom enhance recruitment of commercial species? J. Exp. Mar. Biol. Ecol. 312:299-317.

Gutiérrez, J. L., C. G. Jones, D. L. Strayer \& O. O. Iribarne. 2003. Mollusks as ecosystem engineers: the role of shell production in aquatic habitats. Oikos 101:79-90.

Hare, J. A., W. E. Morrison, M. W. Nelson, M. M. Stachura, E. J. Teeters, R. B. Griffis, M. A. Alexander, J. D. Scott, L. Alade, R. J. Bell, A. S. Chute, K. L. Curtis, T. H. Curtis, D. Kircheis, J. F. Kocik, S. M. Lucey, C. T. McCandless, L. M. Milke, D. E. Richardson, E. Robillard, H. J. Walsh, M. C. McManus, K. E. Marancik \& C. A. Griswold. 2016. A vulnerability assessment of fish and invertebrates to climate change on the northeast U.S. continental shelf. PLoS One 11:e0146756.

Hart, D. R. \& P. J. Rago. 2015. Long-term dynamics of U.S. Atlantic sea scallop Placopecten magellanicus populations. N. Am. J. Fish. Manage. 26:490-501.

Hellberg, M. E. 2009. Gene flow and isolation among populations of marine animals. Annu. Rev. Ecol. Evol. Syst. 40:291-310.

Hennen, D. R., L. D. Jacobson \& J. Tang. 2012. Accuracy of the Patch model used to estimate density and capture efficiency in depletion experiments for sessile invertebrates and fish. ICES J. Mar. Sci. 69:240-249.

Hofmann, E. E., J. M. Klinck, J. N. Kraeuter, E. N. Powell, R. E. Grizzle, S. C. Buckner \& V. M. Bricelj. 2006. A population dynamics model of the hard clam, Mercenaria mercenaria: development of the ageand length-frequency structure of the population. J. Shellfish Res. 25:417-444.

Hofmann, E. E., J. M. Klinck, E. N. Powell, S. Boyles \& M. Ellis. 1994. Modeling oyster populations II. Adult size and reproductive effort. J. Shellfish Res. 13:165-182.

Holt, R. D. 2003. On the evolutionary ecology of species' ranges. Evol. Ecol. Res. 5:159-178.

Holt, R. D., T. H. Keitt, M. A. Lewis, B. A. Maurer \& M. L. Taper. 2005. Theoretical models of species' borders: single species approaches. Oikos 108:18-27.

Hutchins, L. W. 1947. The bases for temperature zonations in geographical distribution. Ecol. Monogr. 17:325-335.

Ibrahim, K. M., R. A. Nichols \& G. M. Hewitt. 1996. Spatial patterns of genetic variation generated by different forms of dispersal during range expansion. Heredity 77:282-291.

Jacobson, L. \& J. Weinberg. 2006. Atlantic surfclam (Spisula solidissima). In: Status of Fishery Resources of the Northeastern US. NOAA NEFSC Resource Evaluation and Assessment Division. 8 pp. Revised December 2006. Available at: http://www.nefsc.noaa. gov/sos/spsyn/iv/surfclam/index.html.

Jones, D. S. 1981. Reproductive cycles of the Atlantic surfclam Spisula solidissima, and the ocean quahog Arctica islandica off New Jersey. J. Shellfish Res. 1:23-32.

Kang, D. \& E. N. Curchitser. 2013. Gulf Stream eddy characteristics in a high-resolution ocean model. J. Geophys. Res. Oceans 118: 4474-4487.

Kim, Y. \& E. N. Powell. 2004. Surfclam histopathology survey along the Delmarva mortality line. J. Shellfish Res. 23:429-441.

Kraeuter, J. N., M. J. Kennish, J. Dobarro, S. R. Fegley \& G. E. Flimlin, Jr. 2003. Rehabilitation of the northern quahog (hard clam) (Mercenaria mercenaria) habitat by shelling-11 years in Barnegat Bay, New Jersey. J. Shellfish Res. 22:61-67.

Kuykendall, K. M., E. N. Powell, J. M. Klinck, P. T. Moreno \& R. T. Leaf. 2017. Management strategy evaluation for the Atlantic surfclam (Spisula solidissima) using a spatially explicit, vessel-based fisheries model. Fish Bull. 115:300-325.

Landi, P., C. Hui \& U. Dieckmann. 2015. Fisheries-induced disruptive selection. J. Theor. Biol. 365:2014-2216. 
Loesch, J. G. \& J. W. Ropes. 1977. Assessments of surf clam stocks in nearshore waters along the Delmarva Peninsula and in the fishery south of Cape Henry. Proc. Natl. Shellfish. Assoc. 67:29-34.

Lucey, S. M. \& J. A. Nye. 2010. Shifting species assemblages in the northeast US continental shelf large marine ecosystem. Mar. Ecol. Prog. Ser. 415:23-33.

Ma, H., J. P. Grassle \& R. J. Chant. 2006. Vertical distribution of bivalve larvae along a cross-shelf transect during summer upwelling and downwelling. Mar. Biol. 149:1123-1138.

MacKenzie, C. L., Jr., D. J. Radosh \& R. N. Reid. 1985. Densities, growth, and mortalities of juveniles of the surf clam (Spisula solidissima) (Dillwyn) in the New York Bight. J. Shellfish Res. 5:81-84.

Martell, S., B. Leaman \& I. Stewart. 2013. Developments in the management strategy evaluation process, fisheries objectives, and implications for harvest policy and decision making. Seattle, WA Int. Pac. Halibut Comm. Report of Assessment and Research Activities. pp. 239-260.

Marzec, R. J., Y. Kim \& E. N. Powell. 2010. Geographic trends in weight and condition index of surfclams (Spisula solidissima) in the Mid-Atlantic Bight. J. Shellfish Res. 29:117-128.

McCay, B. J., S. Brandt \& C. F. Creed. 2011. Human dimensions of climate change and fisheries in a coupled system: the Atlantic surfclam case. ICES J. Mar. Sci. 68:1354-1367.

McCay, B. J., C. F. Creed, A. C. Finlayson, R. Apostle \& K. Mikalsen. 1995. Individual transferrable quotas (ITQs) in Canadian and US fisheries. Ocean Coast. Manage. 28:85-115.

Miller, T. J., J. A. Blair, T. F. Ihde, R. M. Jones, D. H. Secor \& M. J. Wilberg. 2010. FishSmart: an innovative role for science in stakeholder-centered approaches to fisheries management. Fisheries 35:424-433.

Millischer, L. \& D. Gasuel. 2006. Information transfer, behavior of vessels and fishing efficiency: an individual-based simulation approach. Aquat. Living Resour. 19:1-13.

Mouw, C. B. \& J. A. Yoder. 2005. Primary production calculations in the Mid-Atlantic Bight including effects of phytoplankton community size structure. Limnol. Oceanogr. 50:1232-1243.

Munroe, D., D. A. Narváez, D. Hennen, E. E. Hofmann, L. Jacobsen, R. Mann, E. Hofmann, E. N. Powell \& J. Klinck. 2016. Fishing and bottom water temperature as drivers of change in maximum shell length in Atlantic surfclams (Spisula solidissima). Estuar. Coast. Shelf. Sci. 170:112-122.

Munroe, D. M., E. E. Hofmann, E. N. Powell \& J. M. Klinck. 2013a. How do shellfisheries influence genetic connectivity in metapopulations? A modeling study examining the role of lower size limits in oyster fisheries. Can. J. Fish. Aquat. Sci. 70:1813-1828.

Munroe, D. M., E. N. Powell, S. E. Ford, E. E. Hofmann \& J. M. Klinck. 2015. Outcomes of asymmetric selection pressure and larval dispersal on evolution of disease resistance: a metapopulation modeling study with oysters. Mar. Ecol. Prog. Ser. 531:221-239.

Munroe, D. M., E. N. Powell, R. Mann, J. M. Klinck \& E. E. Hofmann. 2013b. Underestimation of primary productivity on continental shelves: evidence from maximum size of extant surfclam (Spisula solidissima) populations. Fish. Oceanogr. 22:220-233.

Narváez, D. A., D. M. Munroe, E. E. Hofmann, J. M. Klinck, E. N. Powell, R. Mann \& E. Curchitser. 2015. Long-term dynamics in Atlantic surfclam (Spisula solidissima) populations: the role of bottom water temperature. J. Mar. Syst. 141:136-148.

NEFSC. 2013. Part A. Atlantic surfclam assessment in the US EEZ for 2013. In: $56^{\text {th }}$ Northeast Regional Stock Assessment Workshop (56 ${ }^{\text {th }} \mathrm{SAW}$ ) assessment report. NEFSC Reference Document 13-10. $491 \mathrm{pp}$.

NEFSC. 2017. $61^{\text {st }}$ Northeast Regional Stock Assessment Workshop $\left(61^{\text {st }}\right.$ SAW) assessment summary report. NEFSC Reference Document 17-05. pp. 1-466.
Neuman, M. 1996. Evidence of upwelling along the New Jersey coastline and the south shore of Long Island, New York. Bull. Nat. J. Acad. Sci. 41:7-13.

NOAA. 2012. Regulatory amendment to open a portion of the Georges Bank Closed Area to the harvest of Atlantic surf clams and ocean quahogs. Fed. Regist. 77:75057-75064.

O'Connor, M. I., J. F. Bruno, S. D. Gaines, B. S. Helpern, S. E. Lester, B. P. Kinlan \& J. M. Weiss. 2007. Temperature control of larval dispersal and the implications for marine ecology, evolution, and conservation. Proc. Natl. Acad. Sci. USA 104:1266-1271.

O'Reilly, J. E. \& D. A. Busch. 1984. Phytoplankton primary production on the northwestern Atlantic shelf. Rapp. P.-v. Réun. Cons. Int Explor. Mer. 183:255-268.

O'Reilly, J. E. \& C. Zetlin. 1998. Seasonal, horizontal, and vertical distribution of phytoplankton chlorophyll a in the northeast US continental shelf ecosystem. Report. Seattle, WA: U.S. Department of Commerce.

Palmer, C. T. 1991. Life and death of a small-scale fishery surf clam dredging in southern Maine. MAST Marit. Anthropol. Stud. 4:56-72.

Parsons-Hubbard, K. M., E. N. Powell, G. M. Staff, W. R. Callender, C. E. Brett \& S. E. Walker. 2001. The effect of burial on shell preservation and epibiont cover in Gulf of Mexico and Bahamas shelf and slope environments after two years: and experimental approach. In: Aller, J. Y., S. A. Woodin \& R. C. Aller, editors. Organism-sediment interactions. Belle W. Baruch Library in Marine Science No. 21. Columbia, SC: University of South Carolina Press. pp. 297-314

Polyakov, O., J. N. Kraeuter, E. E. Hofmann, S. C. Buckner, V. M. Bricelj, E. N. Powell \& J. M. Klinck. 2007. Benthic predators and northern quahog (=hard clam) (Mercenaria mercenaria Linnaeus, 1758) populations. J. Shellfish Res. 26:995-1010.

Powell, E. N. 2003. Maryland inshore surf clam, Spisula solidissima, survey August 2003 cruise report. Final report to J. H. Miles \& Co. Inc. Port Norris, NJ: Haskin Shellfish Research Laboratory. 19 pp.

Powell, E. N., E. E. Hofmann, J. M. Klinck \& S. M. Ray. 1992 Modeling oyster populations 1 . A commentary on filtration rate. Is faster always better? J. Shellfish Res. 11:387-398.

Powell, E. N., J. M. Klinck, E. E. Hofmann, P. Moreno, K. M. Kuykendall, D. M. Munroe \& R. Mann. 2016. Captains' response to a declining stock as anticipated in the surfclam Spisula solidissima fishery on the U.S. Mid-Atlantic coast by model evaluation. Ocean Coast. Manage. 134:52-68

Powell, E. N., J. M. Klinck, D. M. Munroe, E. E. Hofmann, P. Moreno \& R. Mann. 2015a. The value of captains' behavioral choices in the success of the surfclam (Spisula solidissima) fishery on the U.S Mid-Atlantic coast: a model evaluation. J. Northwest Atl. Fish. Sci. 47:1-27.

Powell, E. N., K. M. Kuykendall \& P. Moreno. 2017a. The death assemblage as a marker for habitat and an indicator of climate change: Georges Bank, surfclams and ocean quahogs. Cont. Shelf Res. 142:14-31.

Powell, E. N. \& R. Mann. 2016. How well do we know the infaunal biomass of the continental shelf? Cont. Shelf Res. 115:27-32.

Powell, E. N., R. Mann, K. A. Ashton-Alcox, Y. Kim \& D. Bushek. 2015b. The allometry of oysters: spatial and temporal variation in the length-biomass relationships for Crassostrea virginica. J. Mar. Biol. Assoc. U.K. 96:1127-1144

Powell, E. N., R. Mann, K. A. Ashton-Alcox, K. M. Kuykendall \& M. C. Long. 2017b. Can we estimate molluscan abundance and biomass on the continental shelf? Estuar. Coast. Shelf Sci. 198:213-224.

Powell, E. N. \& R. J. Stanton, Jr. 1985. Estimating biomass and energy flow of molluses in paleo-communities. Palaeontology (Lond.) 28:1-34.

Quijón, P. A., J. P. Grassle \& J. M. Rosario. 2007. Naticid snail predation on early post-settlement surfclams (Spisula solidissima) 
on the inner continental shelf of New Jersey, USA. Mar. Biol. 150:873-882.

Ropes, J. W. 1968. Reproductive cycle of the surf clam, Spisula solidissima, in offshore New Jersey. Biol. Bull. 135:349-365.

Ropes, J. W. 1980. Biological and fisheries data on surf clam, Spisula solidissima (Dillwyn). NEFSC Technical Report Series No. 24. 88 pp.

Ropes, J. W. 1982. The Atlantic coast surf clam fishery, 1965-1974. Mar. Fish. Rev. 44:1-14.

Rowe, G. T., R. Theroux, W. Phoel, H. Quinby, R. Wilke, D. Koschoreck, T. E. Whitledge, P. G. Falkowski \& C. Fray. 1988. Benthic carbon budgets for the continental shelf south of New England. Cont. Shelf Res. 8:511-527.

Roy, K., D. Jablonski \& J. W. Valentine. 2001. Climate change, species range limits and body size in marine bivalves. Ecol. Lett. 4:366-370.

Schofield, O., R. Chant, B. Cahill, R. Castelao, D. Gong, A. Kahl, J. Kohut, M. Montes-Hugo, R. Ramadurai, P. Ramey, X. Yi \& S. Glenn. 2008. The decadal view of the Mid-Atlantic Bight from the COOLroom: is our coastal system changing? Oceanography 21:108-117.

Selkoe, K. A. \& R. J. Toonen. 2011. Marine connectivity: a new look at pelagic larval duration and genetic metrics of dispersal. Mar. Ecol. Prog. Ser. 436:291-305.

Sha, J., Y.-H. Jo, X.-H. Yan \& W. T. Liu. 2015. The modulation of the seasonal cross-shelf sea level variation by the cold pool in the Middle Atlantic Bight. J. Geophys. Res. Oceans 120:7182-7194.

Shanks, A. L. \& L. Brink. 2005. Upwelling, downwelling, and crossshelf transport of bivalve larvae: test of a hypothesis. Mar. Ecol. Prog. Ser. 302:1-12.

Thorarinsdóttir, G. G., L. Jacobson, S. Á. Ragnarsson, E. G. Garcia \& K. Gunnarsson. 2010. Capture efficiency and size selectivity of hydraulic clam dredges used in fishing for ocean quahogs (Arctica islandica): simultaneous estimation in the SELECT model. ICES J. Mar. Sci. 67:345-354.

Tian, R. C., C. Chen, K. D. Stokesbury, B. J. Rothschild, G. W. Cowles, Q. Xu, S. Hu, B. P. Harris \& M. C. Marino, II. 2009. Modeling the connectivity between sea scallop populations in the Middle Atlantic Bight and over Georges Bank. Mar. Ecol. Prog. Ser. 380:147-160.

Travis, J. M. J., M. Delgado, G. Bocedi, M. Baguette, K. Bartoń, D. Bonte, I. Boulangeat, J. A. Hodgson, A. Kubisch, V. Penteriani, M. Saastamoinen, V. M. Stevens \& J. M. Bullock. 2013. Dispersal and species' responses to climate change. Oikos 122:1532-1540.

van der Meer, J. 2006. An introduction to dynamic energy budget (DEB) models with special emphasis on parameter estimation. $J$. Sea Res. 56:85-102.
Waldbusser, G. G., H. Bergschneider \& M. A. Green. 2010. Sizedependent $\mathrm{pH}$ effect on calcification in post-larval hard clam Mercenaria sp. Mar. Ecol. Prog. Ser. 417:171-182.

Walker, S. E., K. Parsons-Hubbard, E. N. Powell \& C. E. Brett. 1998. Bioerosion or bioaccumulation? Shelf-slope trends for epi- and endobionts on experimentally deployed gastropod shells. Hist. Biol. 13:61-72.

Walters, C. 2000. Impacts of dispersal, ecological interactions and fishing effort dynamics on efficacy of marine protected areas: how large should protected areas be? Bull. Mar. Sci. 66:745-757.

Weinberg, J. R. 1998. Density-dependent growth in the Atlantic surfclam, Spisula solidissima, off the coast of the Delmarva Peninsula, USA. Mar. Biol. 130:621-630.

Weinberg, J. R. 1999. Age-structure, recruitment, and adult mortality in populations of the Atlantic surfclam, Spisula solidissima, from 19781997. Mar. Biol. 134:113-125.

Weinberg, J. R. 2005. Bathymetric shift in the distribution of Atlantic surfclams: response to warmer ocean temperature. ICES J. Mar. Sci. 62:1444-1453.

Weinberg, J. R., T. G. Dahlgren \& K. M. Halanych. 2002. Influence of rising sea temperature on commercial bivalve species of the U.S. Atlantic coast. Am. Fish. Soc. Symp. 32:131-140.

Weinberg, J. R., E. N. Powell, C. Pickett, V. A. Nordahl, Jr. \& L. D. Jacobson. 2005. Results from the 2004 cooperative survey of Atlantic surfclams. NEFSC Reference Document, 05-01. pp. 1-41.

Weninger, Q. 1998. Assessing efficiency gains from individual transferrable quotas: an application to the Mid-Atlantic surf clam and ocean quahog fishery. J. Agric. Econ. 80:750-764.

Woodin, S. A., T. J. Hilbish, B. Helmuth, S. J. Jones \& D. S. Wethey. 2013. Climate change, species distribution models, and physiological performance metrics: predicting when biogeographic models are likely to fail. Ecol. Evol. 3:3334-3346.

Yoder, J. A., S. E. Schollaert \& J. E. O’Reilly. 2002. Climatological phytoplankton chlorophyll and sea surface temperature patterns in continental shelf and slope water off the northeast U.S. coast. Limnol. Oceanogr. 47:672-682.

Zhang, X., D. Haidvogel, D. Munroe, E. N. Powell, J. Klinck, R. Mann \& F. S. Castruccio. 2015. Modeling larval connectivity of the Atlantic surfclams within the Middle Atlantic Bight: model development, larval dispersal and metapopulation connectivity. Estuar. Coast. Shelf Sci. 153:38-53.

Zhang, X., D. Munroe, D. Haidvogel \& E. N. Powell. 2016. Atlantic surfclam connectivity within the Middle Atlantic Bight: mechanisms underlying variation in larval transport and settlement. Estuar. Coast. Shelf Sci. 173:65-78. 